\title{
Effects of treating high forage and high concentrate diets with exogenous fibrolytic enzymes on their in vitro ruminal fermentation
}

\author{
L.A. Giraldo ${ }^{1,2}$, M.J. Ranilla ${ }^{1,2,3}$, M.L. Tejido ${ }^{1}$ and M.D. Carro ${ }^{1}$ \\ ${ }^{1}$ Faculty of Agriculture Sciences, National University of Colombia \\ Calle 64 x Carrera 65, Autopista Norte, A.A. 1027 Medellín, Colombia \\ ${ }^{2}$ Department of Animal Production, University of León \\ 24071 León, Spain
}

\begin{abstract}
Batch cultures of mixed rumen microorganisms were used to study the effects of a $24 \mathrm{~h}$ pretreatment with a xylanase from Trichoderma viride (XYL) and a cellulase from Trichoderma longibrachiatum (CEL) on the in vitro fermentation of two diets composed by grass hay and concentrate in the proportions of 70:30 (HF) and 30:70 (HC). In $8 \mathrm{~h}$ incubations with HF, CEL increased $(\mathrm{P}<0.05)$ the production of acetate, propionate and total volatile fatty acids (VFA) and gas, but no effects $(\mathrm{P}>0.05)$ were observed for XYL. In contrast, with HC both enzymes increased $(\mathrm{P}<0.05)$ the production of propionate and total VFA and the true DM degradability of substrate, and decreased the $\mathrm{CH}_{4} /$ VFA ratio $(\mathrm{P}<0.05)$. After $24 \mathrm{~h}$ incubation, some of the observed effects disappeared, but CEL still increased $(\mathrm{P}<0.05)$ the production of acetate, propionate and total VFA for HF. For HC, both enzymes increased $(\mathrm{P}<0.05)$ the production of total VFA and XYL also increased $(\mathrm{P}<0.05)$ acetate production. The results indicate that effects of enzymes on in vitro fermentation were influenced by the nature of the diet, and that this influence varied with the incubation time, being more pronounced at short incubation times.
\end{abstract}

KEY WORDS: exogenous fibrolytic enzymes, ruminal fermentation, batch cultures

\footnotetext{
* Supported by the M.C.Y.T. of Spain, Project AGL2001-0130, and the Junta de Castilla y León (LE040A05)

${ }^{3}$ Corresponding author: e-mail: mjrang@unileon.es
} 


\section{INTRODUCTION}

The use of fibrolytic enzymes as feed additives in ruminant diets has received considerable attention in the last years, despite observed responses have been highly variable. The effects of enzymes are influenced by factors such as type and dose of enzyme, type of diets fed to the animals, and enzyme application method (Beauchemin et al., 2003). To our knowledge, however, no study has been conducted to investigate how the forage:concentrate ratio in the diet can affect the response to enzyme treatment. The objective of this study was therefore to evaluate the effects of two fibrolytic enzymes on the in vitro ruminal fermentation of two diets differing in their forage:concentrate ratio. The study examined the effects of the enzymes at two incubation times, since it has been shown that the response to enzymes usually becomes less marked as incubation time increases (Beauchemin et al., 2003).

\section{MATERIAL AND METHODS}

The diets were composed of grass hay and a commercial concentrate based on barley, maize, soyabean meal and a vitamin-mineral mixture in the proportions (DM basis) of 70:30 (high-forage diet; HF) and 30:70 (high-concentrate diet; HC). Crude protein (CP), neutral-detergent fibre (NDF) and acid-detergent fibre (ADF) contents of diets were 143, 496 and $253 \mathrm{~g} / \mathrm{kg} \mathrm{DM}$ for HF and 176, 376 and $161 \mathrm{~g} / \mathrm{kg}$ DM for HC. Two enzyme preparations commercialized by Fluka Chemie GmbH (Germany) were tested: xylanase from Trichoderma viride (XYL) and cellulase from Trichoderma longibrachiatum (CEL). Enzyme preparations were assayed for endoglucanase, exoglucanase, xylanase and amylase activities following the procedures described by Colombatto and Beauchemin (2003). All activities were measured at $\mathrm{pH} 6.5$ and $39^{\circ} \mathrm{C}$ in order to resemble optimal ruminal conditions. At $\mathrm{pH} 6.5$ and $39^{\circ} \mathrm{C}, 1 \mathrm{mg}$ of XYL liberated per min $15.0 \mu \mathrm{mol}$ of xylose from oat spelt xylan and $0.237 \mu \mathrm{mol}$ of glucose from carboxymethylcellulose, but no amylase and exoglucanase activities were detected. One mg of CEL liberated 1.72 $\mu \mathrm{mol}$ of xylose from oat spelt xylan, and 2.40, 0.385 and $0.040 \mu \mathrm{mol}$ of glucose from carboxy-methylcellulose, soluble starch and Avicel PH-101, respectively. One enzymatic unit was defined as the amount of enzyme required to release 1 $\mu \mathrm{mol}$ of xylose or glucose per min from the corresponding substrate at $39^{\circ} \mathrm{C}$ and $\mathrm{pH} 6.5$, and both enzyme preparations were added at a rate of 40 enzymatic units/g substrate DM.

Samples $(500 \mathrm{mg}$ ) of ground diet (1-mm screen) were accurately weighed into $120-\mathrm{ml}$ serum bottles. Solutions of each enzyme preparation were prepared in 0.1 $\mathrm{M}$ sodium phosphate buffer ( $\mathrm{pH} 6.5$ ), $0.5 \mathrm{ml}$ of the corresponding solution were 
added directly to each bottle $24 \mathrm{~h}$ before starting the incubation, and bottles were kept at room temperature $\left(21-23^{\circ} \mathrm{C}\right)$ until incubation. The inoculum was obtained from four rumen-cannulated Merino sheep fed $500 \mathrm{~g}$ of grass hay and $500 \mathrm{~g}$ of concentrate per day administered in two equal portions at 09.00 and $18.00 \mathrm{~h}$. Ruminal contents of each sheep were obtained immediately before the morning feeding, mixed and strained through four layers of cheesecloth. Particle-free fluid was mixed with the buffer solution of Goering and Van Soest (1970; no trypticase added) in a proportion $1: 4(\mathrm{vol} / \mathrm{vol})$ at $39^{\circ} \mathrm{C}$ under continuous flushing with $\mathrm{CO}_{2}$. Fifty $\mathrm{ml}$ of buffered ruminal fluid were added into each bottle under $\mathrm{CO}_{2}$ flushing, bottles were sealed with rubber stoppers and aluminium caps, and incubated at $39^{\circ} \mathrm{C}$ for 8 and $24 \mathrm{~h}$. Four incubation runs were performed on different days, and in each of them one bottle per treatment was included.

After 8 and $24 \mathrm{~h}$ of incubation, total gas production was measured in all bottles using a pressure transducer and a calibrated syringe, and a gas sample (about $15 \mathrm{ml}$ ) from each bottle was stored in a vacuum tube before analysis for $\mathrm{CH}_{4}$ concentration. Bottles were then uncapped, the $\mathrm{pH}$ was immediately measured and the fermentation was stopped by swirling the bottles in ice. Two $\mathrm{ml}$ of the bottle content were taken for VFA and $\mathrm{NH}_{3}-\mathrm{N}$ analyses. Finally, the content of the bottles was transferred to previously weighed filter crucibles, the solid residue was washed with $50 \mathrm{ml}$ of hot distilled water $\left(50^{\circ} \mathrm{C}\right)$ and the crucibles were dried at $50^{\circ} \mathrm{C}$ for $48 \mathrm{~h}$. Residues were analysed for NDF to estimate true DM degradability (TDMD) and NDF degradability (NDFD). Procedures for analysis of CP, NDF, $\mathrm{ADF}, \mathrm{VFA}, \mathrm{CH}_{4}$ and $\mathrm{NH}_{3}-\mathrm{N}$ have been described by Carro et al. (1999).

Data from each incubation time were analysed independently. When data from both enzymatic treatments and diets were analysed together, significant enzyme $\mathrm{x}$ diet interactions $(\mathrm{P}<0.05)$ were observed for some variables. Therefore, data were analysed separately for each diet as an ANOVA with three enzyme treatments (control (CON), XYL and CEL) and four incubation runs (blocking factor) as main effects. When a significant effect of the enzyme treatment $(\mathrm{P}<0.05)$ were detected, differences between means were assessed by the LSD test.

\section{RESULTS AND DISCUSSION}

The effects of the treatment with fibrolytic enzymes on in vitro fermentation of diets after 8 and $24 \mathrm{~h}$ of incubation with rumen mixed microorganisms are shown in Tables 1 and 2, respectively. For HF, there were no effects $(\mathrm{P}>0.05)$ of enzymes on final $\mathrm{pH}, \mathrm{CH}_{4}$ production, $\mathrm{NH}_{3}-\mathrm{N}$ concentration and TDMD at any incubation time. After $8 \mathrm{~h}$ of incubation and with HF, CEL treatment increased $(\mathrm{P}<0.05)$ the production of gas, acetate, propionate and total VFA by 11,10 , 23 and $13 \%$, respectively, but no effects of XYL $(\mathrm{P}>0.05)$ were detected. In 
contrast, for $\mathrm{HC}$ both enzymes decreased $(\mathrm{P}<0.05)$ final $\mathrm{pH}$ and $\mathrm{CH}_{4}$ :VFA ratio, and increased $(\mathrm{P}<0.05)$ TDMD and the production of propionate and total VFA. These results indicate that CEL was more effective than XYL with HF, but only subtle differences were observed between the effects of both enzymes on in vitro fermentation of HC. The treatment with XYL implied mainly xylanase activity, as endoglucanase and amylase activities were negligible. Compared to XYL, CEL presented lower xylanase activity, but greater endoglucanase, exoglucanase and amylase activities. Eun and Beauchemin (2007) suggested that limiting enzymatic activity is likely substrate dependent. The lack of effect of XYL on fermentation of HF diet might be partly explained if endoglucanase activity would have been the limiting activity for this diet. However, for HC diet XYL and CEL produced similar effects on some ruminal variables at $8 \mathrm{~h}$. These results indicate again that the enzymatic activities required to enhance ruminal degradation are influenced by the nature of the incubated substrates. As pointed out by Wallace et al. (2001), a precisely identification of the enzymatic activity causing a positive response in ruminal fermentation might make possible to develop more effective fibrolytic enzyme products.

Table 1. Influence of two enzymatic treatments on in vitro fermentation of two diets (500 $\mathrm{mg} \mathrm{DM})$ in batch cultures of mixed rumen microorganisms for $8 \mathrm{~h}(\mathrm{n}=4)$

\begin{tabular}{|c|c|c|c|c|c|c|c|c|}
\hline \multirow{2}{*}{ Treatment $^{1}$} & \multicolumn{4}{|c|}{ High-forage diet (HF) } & \multicolumn{4}{|c|}{ High-concentrate diet (HC) } \\
\hline & $\mathrm{CON}$ & XYL & CEL & $\overline{\text { s.e.d. }}{ }^{2}$ & $\mathrm{CON}$ & XYL & CEL & s.e.d. ${ }^{2}$ \\
\hline$\overline{\mathrm{PH}}$ & 6.73 & 6.73 & 6.73 & 0.016 & $6.59^{\mathrm{b}}$ & $6.54^{\mathrm{a}}$ & $6.54^{\mathrm{a}}$ & 0.013 \\
\hline Gas, $\mu \mathrm{mol}$ & $2127^{\mathrm{a}}$ & $2235^{\mathrm{ab}}$ & $2350^{\mathrm{b}}$ & 47.8 & $2465^{\mathrm{a}}$ & $2480^{\mathrm{a}}$ & $2563^{\mathrm{b}}$ & 16.3 \\
\hline $\mathrm{CH}_{4}, \mu \mathrm{mol}$ & 379 & 395 & 393 & 10.0 & 482 & 498 & 497 & 12.0 \\
\hline $\mathrm{NH}_{3}-\mathrm{N}, \mathrm{mg} / \mathrm{l}$ & 160 & 159 & 168 & 8.0 & 186 & 178 & 185 & 2.43 \\
\hline TDMD, $\%$ & 497 & 502 & 510 & 0.6 & $591^{\mathrm{a}}$ & $626^{\mathrm{b}}$ & $619^{b}$ & 0.573 \\
\hline Total VFA, $\mu \mathrm{mol}$ & $1572^{\mathrm{a}}$ & $1538^{\mathrm{a}}$ & $1772^{\mathrm{b}}$ & 29.7 & $1829^{a}$ & $2045^{b}$ & $2158^{\mathrm{b}}$ & 46.5 \\
\hline Acetate, $\mu \mathrm{mol}$ & $973^{\mathrm{a}}$ & $960^{\mathrm{a}}$ & $1070^{\mathrm{b}}$ & 16.3 & $1056^{\mathrm{a}}$ & $1108^{\mathrm{ab}}$ & $1239^{b}$ & 49.7 \\
\hline Propionate, $\mu \mathrm{mol}$ & $400^{\mathrm{a}}$ & $391^{\mathrm{a}}$ & $492^{\mathrm{b}}$ & 11.3 & $507^{\mathrm{a}}$ & $617^{b}$ & $640^{\mathrm{b}}$ & 22.7 \\
\hline Butyrate, $\mu \mathrm{mol}$ & 148 & 139 & 156 & 5.9 & 214 & 248 & 207 & 18.4 \\
\hline $\mathrm{Ac} / \mathrm{Pr}, \mathrm{mol} / \mathrm{mol}$ & $2.43^{\mathrm{b}}$ & $2.45^{\mathrm{b}}$ & $2.18^{\mathrm{a}}$ & 0.047 & 2.09 & 1.82 & 1.95 & 0.096 \\
\hline $\mathrm{CH}_{4} / \mathrm{VFA}, \mathrm{mol} / \mathrm{mol}$ & $0.242^{\mathrm{b}}$ & $0.257^{\mathrm{a}}$ & $0.222^{\mathrm{c}}$ & 0.0053 & $0.263^{\mathrm{b}}$ & $0.244^{\mathrm{a}}$ & $0.232^{\mathrm{a}}$ & 0.0069 \\
\hline
\end{tabular}

${ }^{1}$ treatments, CON - control, XYL - xylanase from Trichoderma viride, CEL - cellulase from Trichoderma longibrachiatum. Both enzymes were applied at a level of 40 enzymatic units/g of substrate DM

${ }^{2}$ standard error of the difference

a,b,c for each diet, mean values within a row with unlike superscript letters $\operatorname{differ}(\mathrm{P}<0.05)$

Several studies (Wang et al., 2001; Giraldo et al., 2007) have reported that treating different feeds with fibrolytic enzymes produced a shift in the molar proportions of VFA, but shifts in pattern of VFA seem to be influenced by the type 
of diet and enzyme preparations. In the present study, CEL treatment decreased significantly the acetate:propionate ratio at $8 \mathrm{~h}$ of incubation for $\mathrm{HF}$, indicating a change in fermentation pattern. Wang et al. (2001) suggested that changes in fermentation pattern may reflect a shift in the species profile of colonizing bacteria in response to pre-treatment of feed with exogenous enzymes.

Table 2. Influence of two enzymatic treatments on in vitro fermentation of two diets ( $500 \mathrm{mg} \mathrm{DM})$ in batch cultures of mixed rumen microorganisms for $24 \mathrm{~h}(\mathrm{n}=4)$

\begin{tabular}{lcccccccc}
\hline \multirow{2}{*}{ Treatment $^{1}$} & \multicolumn{3}{c}{ High-forage diet (HF) } & \multicolumn{4}{c}{ High-concentrate diet (HC) } \\
\cline { 2 - 9 } & CON & XYL & CEL & s.e.d. $^{2}$ & CON & XYL & CEL & s.e.d..$^{2}$ \\
\hline $\mathrm{pH}$ & 6.65 & 6.62 & 6.61 & 0.054 & 6.45 & 6.44 & 6.43 & 0.014 \\
$\mathrm{Gas}, \mu \mathrm{mol}$ & 5143 & 5017 & 5322 & 47.5 & 4868 & 4922 & 4963 & 23.3 \\
$\mathrm{CH}_{4}, \mu \mathrm{mol}$ & 820 & 857 & 889 & 10.9 & 879 & 923 & 923 & 29.3 \\
$\mathrm{NH}_{3}-\mathrm{N}, \mathrm{mg} / \mathrm{l}$ & 296 & 287 & 284 & 22.8 & 351 & 337 & 328 & 8.7 \\
$\mathrm{TDMD}, \%$ & 63.5 & 64.0 & 66.9 & 1.29 & 75.5 & 75.0 & 75.5 & 0.57 \\
$\mathrm{NDFD}, \%$ & $26.5^{\mathrm{a}}$ & $30.5^{\text {ab }}$ & $33.4^{\mathrm{b}}$ & 1.54 & 33.8 & 33.5 & 35.2 & 1.23 \\
Total VFA, $\mu \mathrm{mol}$ & $2812^{\mathrm{a}}$ & $2888^{\mathrm{a}}$ & $3080^{\mathrm{b}}$ & 57.3 & $3444^{\mathrm{a}}$ & $3551^{\mathrm{b}}$ & $3560^{\mathrm{b}}$ & 38.5 \\
Acetate, $\mu \mathrm{mol}$ & $1697^{\mathrm{a}}$ & $1788^{\mathrm{ab}}$ & $1869^{\mathrm{b}}$ & 33.4 & $1957^{\mathrm{a}}$ & $2100^{\mathrm{b}}$ & $2028^{\mathrm{ab}}$ & 44.1 \\
Propionate, $\mu \mathrm{mol}$ & $642^{\mathrm{a}}$ & $630^{\mathrm{a}}$ & $715^{\mathrm{b}}$ & 15.7 & $834^{\mathrm{a}}$ & $843^{\mathrm{a}}$ & $885^{\mathrm{b}}$ & 12.5 \\
Butyrate, $\mu \mathrm{mol}$ & 322 & 324 & 332 & 8.0 & 469 & 466 & 448 & 9.0 \\
Ac/Pr, mol/mol & $2.65^{\mathrm{b}}$ & $2.84^{\mathrm{b}}$ & $2.62^{\mathrm{a}}$ & 0.046 & 2.35 & 2.50 & 2.31 & 0.077 \\
$\mathrm{CH}_{4} / \mathrm{VFA}, \mathrm{mol} / \mathrm{mol}$ & 0.291 & 0.297 & 0.288 & 0.0072 & 0.254 & 0.261 & & 0.0087 \\
\hline
\end{tabular}

${ }^{1}$ treatments, CON - control, XYL - xylanase from Trichoderma viride, CEL - cellulase from Trichoderma longibrachiatum. Both enzymes were applied at a level of 40 enzymatic units/g of substrate DM

${ }^{2}$ standard error of the difference

a,b,c for each diet, mean values within a row with unlike superscript letters differ $(\mathrm{P}<0.05)$

Some of the observed effects of enzymes disappeared after $24 \mathrm{~h}$ of incubation, but CEL still increased $(\mathrm{P}<0.05)$ the production of acetate, propionate and total VFA by 10,11 and $9.5 \%$, respectively, for HF; in contrast, no effects $(\mathrm{P}>0.05)$ of XYL were detected for these diet. Regarding HC, both CEL and XYL increased total VFA by 2.8 and $3.1 \%$, respectively. For both diets, the effects of enzymes were more marked at 8 than at $24 \mathrm{~h}$ of fermentation, thus indicating that enzymes produced their effects at early stages of fermentation. Previous studies (Beauchemin et al., 2003; Giraldo et al., 2007) have also shown that effects of fibrolytic enzyme on in vitro fermentation were generally larger during the initial stages of degradation.

In general, effects of CEL on in vitro fermentation of diets were more marked than those of XYL. Although CEL was effective with both substrates, lower effects were observed for $\mathrm{HC}$ compared to HF. The results of this study indicate that effects of enzymes on in vitro fermentation were influenced by the nature 
of the diet, and that this influence varied with the incubation time, being more pronounced at short incubation times.

\section{ACKNOWLEDGEMENTS}

\section{L.A. Giraldo gratefully acknowledges receipt of a grant from the Fundation Carolina.}

\section{REFERENCES}

Beauchemin K.A., Colombatto D., Morgavi D.P., Yang W.Z., 2003. Use of exogenous fibrolytic enzymes to improve feed utilization by ruminants. J. Anim. Sci. 81, Suppl. 2, E37-E47

Carro M.D., López S., Valdés C., Ovejero F.J., 1999. Effect of DL-malate on mixed ruminal microorganism fermentation using the rumen simulation technique (RUSITEC). Anim. Feed Sci. Tech. 79, 279-288

Colombatto D., Beauchemin K.A., 2003. A proposed methodology to standarize the determination of enzymatic activities present in enzyme additives used in ruminant diets. Can. J. Anim. Sci. $83,559-568$

Eun J.S., Beauchemin K.A., 2007. Assesment of the efficacy of varying experimental exogenous fibrolytic enzymes using in vitro fermentation characteristics. Anim. Feed Sci. Tech. 132, 298315

Giraldo L.A., Tejido M.L., Ranilla M.J., Carro M.D., 2007. Effects of exogenous cellulase supplementation on microbial growth and ruminal fermentation of a high-forage diet in Rusitec fermenters. J. Anim. Sci. (in press)

Goering M.K., Van Soest P.J., 1970. Forage Fiber Analysis (Apparatus, Reagents, Procedures and Some Applications). Agricultural Handbook, No. 379. Agricultural Research Services, USDA. Washington, DC

Wallace R.J., Wallace S.J.A., McKain N., Nsereko V.L., Hartnell G.F., 2001. Influence of supplementary fibrolytic enzymes on the fermentation of corn and grass silages by mixed ruminal microorganisms in vitro. J. Anim. Sci. 79, 1905-1916

Wang Y., McAllister T.A., Rode L.M., Beauchemin K.A., Morgavi D.P., Nsereko V.L., Iwaasa A.D., Yang W., 2001. Effects of an exogenous enzyme preparation on microbial protein synthesis, enzyme activity and attachment to feed in the Rumen Simulation Technique (Rusitec). Brit. J. Nutr. 85, 325-332 